\title{
Recht en Utilisme Een pleidooi voor het utilisme als richtlijn voor de wetgever
}

\author{
Jaap Hage
}

\section{Inleiding}

In dit artikel wil ik proberen opnieuw belangstelling te wekken voor het programma van Bentham om het utilisme te hanteren als richtlijn voor de wetgever. De wetgever zou regels moeten maken die de totale hoeveelheid geluk maximaliseren. Ik wil niet suggereren dat wetgevers momenteel niet zouden proberen zo goed mogelijke regels te maken. Maar ik denk dat er momenteel geen consistent beleid is bij het bepalen van wat regels goed maakt. Er wordt vaak ad hoc gereageerd op problemen die zich voordoen en het beleid dat er is wordt eerder bepaald door politieke ideologieën en bestaande machtsverhoudingen dan door systematisch onderzoek naar wat mensen gelukkig maakt. En dat laatste zou mijns inziens moeten gebeuren.

Het is wellicht goed om direct al een mogelijk misverstand uit de weg te ruimen. Een pleidooi voor utilisme als richtlijn voor de wetgever is geen pleidooi om de wetgever elk wetsvoorstel te laten toetsen aan het gelukscriterium. Het utilisme beoogt een abstracte maatstaf te bieden die kan dienen om richting te geven aan meer concrete maatstaven zoals het bestrijden van armoede en het bevorderen van scholing en werkgelegenheid. De waarde van het utilisme is ten minste tweeledig. In de eerste plaats biedt het een richtlijn om te bepalen of een bepaald beleidsdoel, bijvoorbeeld het onbeperkt toelaten van vluchtelingen uit oorlogsgebieden, een goed doel is. In de tweede plaats vormt het een criterium voor prioritering als goede beleidsdoelen in een concreet geval conflicteren. Wat moet er bijvoorbeeld voorrang hebben als vrijheid van meningsuiting conflicteert met het streven om uitingen die anderen kwetsen te vermijden?

Mijn betoog ziet er in grote lijnen als volgt uit. In paragraaf 2 zal ik aangeven wat het utilisme aantrekkelijk maakt als richtlijn voor de wetgever. In de paragrafen 3 en 4 zal ik proberen een aantal van de belangrijkste bezwaren tegen het utilisme te weerleggen. In paragraaf 3 gaat het vooral om het bezwaar dat het utilisme sommige mensen aan andere mensen opoffert, of dat het toelaat de rechten van mensen te schenden. In paragraaf 4 staat het bezwaar centraal dat het utilisme soms leidt tot waardeoordelen die sterk contra-intuïtief zijn. Het zal blijken dat de weerlegging van deze bezwaren het nodig maakt tamelijk diep in te gaan op de methode van normatief onderzoek. Daarom is het belangrijkste deel van paragraaf 4 gewijd aan een korte bespreking van het coherentisme als methode in kennisleer en ethiek. Ten slotte zal ik paragraaf 5 wijden aan een korte vergelijking met Rawls' theorie over rechtvaardigheid. Ik maak juist deze vergelijking omdat 
bij Rawls de rechten van individuen een centrale plaats innemen, terwijl er binnen het utilisme geen centrale plaats is voor individuele rechten.

In mijn pleidooi voor het utilisme zal ik een tweevoudige strategie hanteren. Enerzijds zal ik het utilisme niet verdedigen als een algemene ethische theorie, maar enkel als richtlijn voor de wetgever. Dit betekent dat het logisch bezien met elkaar te verenigen is dat het utilisme aanvaard zou moeten worden als richtlijn voor een wetgever, terwijl het voor een individueel persoon onverstandig en in die zin verkeerd zou kunnen zijn gedrag te laten bepalen door wat de totale hoeveelheid geluk maximaliseert. Ten gevolge van deze aanpak vervalt het bezwaar dat het utilisme van mensen zou verlangen dat ze zichzelf opofferen voor het collectief. Het is veel aannemelijker dat de wetgever een collectief belang moet behartigen dan dat elk individueel persoon dat zou moeten doen.

Anderzijds wordt een bepaalde strategie om bezwaar te maken tegen utilisme verworpen. Die strategie houdt in dat een beroep wordt gedaan op morele intuïties in de zin van gevoelsmatige inschattingen van de morele kwaliteiten van een handeling of situatie. Er wordt dan betoogd dat het utilisme leidt tot contra-intuitieve waardeoordelen. Ik zal in paragraaf 4 betogen dat intuïties niet geheel zonder belang zijn in morele discussies, maar dat hun belang beperkt is. Als morele intuïties niet zo belangrijk zijn, is strijd met morele intuïties geen belangrijk bezwaar.

Er bestaat erg veel literatuur over het utilisme en er zijn vele bezwaren geformuleerd. Het is onmogelijk om daar allemaal op in te gaan. Voor een aantal kwesties heb ik enkel verwezen naar overzichtspublicaties over het utilisme van Driver en Sinnott-Armstrong. ${ }^{1}$ Mijn schrijfstijl zal hierdoor soms wat apodictisch zijn, maar ik hoop en denk dat mijn betoog ook stand zou houden als meer literatuur expliciet in de discussie zou worden betrokken.

\section{Voordelen van utilisme}

Centrale gedachten van het utilisme zoals dat hier zal worden verdedigd zijn dat:

- regelgeving enkel wordt beoordeeld op zijn gevolgen;

- de enige gevolgen die ertoe doen betrekking hebben op de hoeveelheid geluk die door de regelgeving teweeg wordt gebracht;

- het erom te doen is de totale hoeveelheid geluk ${ }^{2}$ te maximaliseren; en

- het er niet toe doet bij wie het geluk terechtkomt, ${ }^{3}$ zodat een grotere hoeveelheid geluk bij sommigen kan compenseren voor minder geluk bij anderen.

1 Driver 2012 en Sinnott-Armstrong 2014.

2 Ik zal hier niet ingaan op de kwestie of het gaat om de totale hoeveelheid geluk zonder meer, of om de gemiddelde hoeveelheid geluk, dus de totale hoeveelheid, gedeeld door het aantal geluksdragers. Meer hierover in Driver 2012, p. 68-74.

3 Ik zal in deze bijdrage niet ingaan op de belangrijke kwestie of in dit verband enkel mensen meetellen, of ook dieren. Ook ga ik niet in op de problematiek rond toekomstige generaties. 
De hier voorgestane versie van utilisme wordt gekenmerkt door enkele belangrijke voordelen.

\subsection{Enkel gevolgen zijn belangrijk}

Het eerste voordeel van het utilisme is dat het de waarde van wetgeving enkel beoordeelt op grond van de gevolgen (consequentialisme). Een concrete wet wordt niet als goed of slecht beschouwd enkel omdat hij een bepaald soort gedrag voorschrijft, verbiedt of toelaat en omdat dat soort gedrag nu eenmaal goed of slecht is. Zo is een wet die prostitutie toelaat niet slecht om de enkele reden dat prostitutie slecht is, al aannemende dat dit zo zou zijn.

Wetgeving is volgens het utilisme niet goed of slecht enkel op grond van de onbeargumenteerde morele kwalificatie van het genormeerde gedrag, maar enkel goed of slecht om een reden die in laatste instantie te maken moet hebben met de gevolgen van de regelgeving. Door de waardering van wetgeving op deze manier te koppelen aan de gevolgen van die wetgeving wordt de irrationaliteit van 'Dit soort gedrag is nu eenmaal verkeerd' vermeden.

\subsection{Uiteindelijk telt enkel geluk}

Het tweede voordeel is dat de gevolgen die tellen voor de waarde van wetgeving in laatste instantie enkel geluk betreffen. Dat (menselijk) geluk een belangrijke rol moet spelen bij het beoordelen van wetgeving wordt zelden betwist. Wellicht is de brede aanvaarding van geluk als maatstaf voor de waarde van handelingen mede te danken aan het feit dat de notie 'geluk' verre van eenduidig is. Het is evenwel de vraag of een eenduidig geluksbegrip nodig is om een beleid te kunnen voeren dat gericht is op geluksmaximalisatie. ${ }^{4}$

Mensen streven van nature naast overleven ook geluk na, ${ }^{5}$ ij het meestal in de vorm van andere dingen zoals gezondheid, vriendschap, kennis en andere waardevolle zaken. Daarover zo meer. Maar het lijkt een voorbeeld van de naturalistische drogreden om uit het gegeven dat mensen iets nastreven op te maken dat het nastrevenswaardig is. Toch is dat niet per se het geval. Hieronder (in par. 4.5) zal ik pleiten voor een coherentiebenadering voor de vraag wat we gerechtigd zijn om te accepteren. Daar zal worden betoogd dat het feit dat we de facto geluk als waarde accepteren, in combinatie met het feit dat we geen redenen hebben om dat niet meer te doen, voldoende rechtvaardiging is voor de conclusie dat we gerechtigd zijn om geluk als waarde te hanteren.

Met de stelling dat het bij utilisme gaat om geluk sluit ik een alternatief uit, namelijk dat het bij utilisme zou gaan om voorkeuren. Voorkeuren zijn weliswaar eenvoudiger te meten, ${ }^{6}$ maar meetbaarheid is niet bepalend voor de kwestie of een handeling goed of slecht is. Het beslissende nadeel van het werken met voor-

Meer daarover in Driver 2012, p. 82-84.

4 Meer hierover in Haybron 2011.

5 Daar wijst Bentham ook op, direct al aan het begin van zijn An Introduction to the Principles of Morals and Legislation (Bentham 1789, hoofdstuk I, par. 1).

6 De discussie meetbaarheid/relevantie staat centraal in Dolan \& Peasgood 2008. 
keuren in plaats van geluk is dat voorkeuren irrationeel kunnen zijn. Voorkeuren kunnen bijvoorbeeld gebaseerd zijn op onjuiste voorstellingen van zaken en dan is het lang niet zeker dat het volgen van voorkeuren leidt tot een maximalisatie van geluk. ${ }^{7}$ Met geluk is het anders. Als mensen ten gevolge van een verkeerde voorstelling van zaken gelukkiger worden, ook op langere termijn, dan pakt de verkeerde voorstelling van zaken juist goed uit. Het bevorderen van geluk, en niet enkel wat mensen denken dat hun gelukkig zal maken, is steeds rationeel.

Het utilisme meet in laatste instantie alle handelingen af aan de totale hoeveelheid geluk die ze teweegbrengen. Dat roept de vraag op of er naast geluk nog andere waarden zijn die net zo'n belangrijke rol zouden moeten spelen. Een hard bewijs dat dit niet zo is valt moeilijk te geven, maar het is mogelijk om in ieder geval wat argumenten noemen. Stel dat er naast geluk ook andere waardevolle dingen zouden zijn, zoals kennis, vrijheid, en vriendschap en dat die dingen hun waarde intrinsiek zouden hebben en niet enkel omdat en voor zover ze bijdragen aan geluk. Dan zou het soms rationeel zijn om geluk, al was het maar een klein beetje, op te offeren omwille van meer vrijheid, vriendschap, of kennis. Omgekeerd geldt dan dat als een dergelijke opoffering nooit rationeel zou zijn, dit ervoor pleit dat de andere waarden slechts instrumentele waarden zijn, die hun waarde ontlenen aan hun bijdrage aan geluk. ${ }^{8}$

Het is niet aannemelijk dat het ooit voor een individu rationeel zou zijn om ongelukkiger te worden ten behoeve van vrijheid, kennis of vriendschap. Evenmin zou het voor een samenleving rationeel zijn om de totale hoeveelheid geluk te doen afnemen ten behoeve van deze waarden. Dat sommigen desondanks bereid zouden zijn om geluk op te offeren ten behoeve van bijvoorbeeld vrijheid is geen hard bewijs dat vrijheid een intrinsieke waarde is naast geluk, want het gaat er niet om waar mensen feitelijk de voorkeur aan geven, maar waaraan ze de voorkeur zouden geven als ze rationeel zouden zijn. ${ }^{9}$ Dit onderscheid tussen daadwerkelijke en rationele voorkeuren is belangrijk en het komt terug in paragraaf 4 als het onderscheid tussen intuïtieve en gerechtvaardigde waardeoordelen.

Een alternatieve verklaring waarom het nooit rationeel zou zijn om geluk op te offeren aan een andere waarde zou zijn dat geluk een 'aggregatiegevoel' is. ${ }^{10}$ Daarmee is bedoeld dat iemand niet gelukkig is naast het feit dat hij gezond is, geen pijn lijdt, vrienden heeft en aangenaam werk. Het is ook niet zo dat deze positieve aspecten van zijn bestaan geluk veroorzaken in de zin van oorzaak en gevolg. Het geluk zou volgens deze verklaring worden geconstitueerd door de ervaring van deze factoren tezamen en daar de optimale combinatie van zijn. Het bestaat uit de

7 Sinnott-Amstrong 2014 (voor het laatst bezocht op 9 december 2014). Zie ook Driver 2012, p. 34-36.

8 Het is in theorie mogelijk dat ook vrijheid een intrinsieke waarde is, maar dat het 'gewicht' van geluk zoveel groter is dan dat van vrijheid, dat geluk het bij een conflict altijd zou winnen van vrijheid.

9 Alexander Hoogenboom wees me erop dat hier een kantiaans element in mijn opvattingen herkenbaar is. Hij heeft gelijk, maar mijns inziens is dat element goed te verenigen met een pleidooi voor utilisme. Vergelijk ook de opvatting van Parfit (2011, p. 419) dat kantianen, contracttheoretici en consequentialisten dezelfde berg beklimmen, zij het van verschillende kanten. Ik heb de term 'aggregatiegevoel' zelf verzonnen en geef hem graag voor beter. 
ervaring van al deze positieve factoren tezamen, maar is er niet enkel de som van. Mensen zijn blijkbaar in staat om op basis van de wijzen waarop het goed en slecht met hen gaat een aggregatiegevoel te genereren dat wordt beschreven in termen van geluk. Iets in de stijl van 'Weliswaar heb ik nu even geen baan, maar ik ben gezond en heb goede vrienden. Dus ben ik nog best wel gelukkig'. Als deze visie op geluk bij benadering juist zou zijn, dan is het niet zo dat geluk de enige intrinsieke waarde is, maar wel zo dat het onverstandig zou zijn om geluk aan iets anders op te offeren, zelfs als dat andere (ook) een intrinsieke waarde is.

Voor het utilisme maakt het weinig uit of geluk de enige intrinsieke waarde is, of dat het een aggregatiegevoel is zoals hierboven beschreven. In beide gevallen is het verstandig om geluk te maximaliseren en al het andere te zien als middel om dat te doen.

\subsection{Bijkomende voordelen}

Er zijn nog een paar voordelen aan het utilisme verbonden, maar dat zijn enkel bijkomende voordelen als men al aanvaardt dat de wetgever het utilisme zou moeten hanteren als richtlijn. Het zijn geen voordelen die de wetgever daartoe zouden moeten bewegen.

Het eerste van deze voordelen is dat als men het utilisme aanvaardt, de rest van het onderzoek naar hoe de wetgeving zou moeten luiden in beginsel aan de wetenschap kan worden overgelaten. Het gaat namelijk om de empirische vraag welke wetgeving zal leiden tot de maximale hoeveelheid geluk. Dat is zeker geen vraag die gemakkelijk te beantwoorden is, maar de moeilijkheid is praktisch, niet principieel. Ik kom daar overigens nog op terug in paragraaf 3.1.

Het tweede bijkomende voordeel is dat alle beleidsdoeleinden die de wetgever moet nastreven instrumenteel zijn ten aanzien van het maximale geluk. Dit betekent dat als er een conflict zou ontstaan tussen twee doeleinden, bijvoorbeeld het bevorderen van de vrijheid van meningsuiting en het voorkomen van hate speech, er een test is die de knoop kan doorhakken, namelijk welke wet zou leiden tot het meeste geluk. Zoals hierboven al werd betoogd doet het feit dat het heel moeilijk kan zijn om te voorspellen wat tot het meeste geluk leidt, hier niet aan af.

\section{Drie 'nadelen' van utilisme}

Op het eerste gezicht heeft het utilisme aantrekkelijke eigenschappen, maar in de loop der jaren zijn er ook vele bezwaren tegen het utilisme geformuleerd. Het is hier niet mogelijk om op al die bezwaren in te gaan, maar een viertal belangrijke bezwaren wil ik toch nadrukkelijk bespreken:

a. Het is onmogelijk om te voorspellen wat leidt tot het meeste geluk.

b. De wetgever moet niet nastreven wat het volk gelukkig maakt, maar wat het volk wil. Wetgeving moet daarom worden gerechtvaardigd door een procedure die de wil van het volk tot uitdrukking brengt. 
c. Het utilisme laat toe dat de belangen, of zelfs de rechten, van sommigen worden opgeofferd aan de belangen van anderen.

d. Het utilisme leidt in een aantal gevallen tot waardeoordelen of gedragsvoorschriften die sterk contra-intuïtief zijn.

De eerste drie bezwaren komen in deze paragraaf aan de orde. Het vierde bezwaar raakt direct aan methodische aspecten van normatief redeneren en ik zal er daarom in een afzonderlijke paragraaf (par. 4) uitvoeriger op ingaan.

\subsection{De onmogelijkheid om vast te stellen wat leidt tot het meeste geluk}

Als een wetgever probeert regels te maken die de hoeveelheid geluk in de samenleving maximaliseren, moet hij kunnen voorspellen wat die hoeveelheid geluk zal maximaliseren. Er zijn aan die voorspelling ten minste twee aspecten verbonden. Om te beginnen is het nodig om te weten waar mensen gelukkig van worden en welke maatschappelijke arrangementen dat bevorderen. Hoeveel gelijkheid moet er zijn? Moet er gratis - dat wil zeggen: collectief betaald - onderwijs zijn? En gratis gezondheidszorg? Moet discriminatie door particulieren worden verboden, of moet er ook in dat opzicht juist vrijheid worden bevorderd? Dit zijn moeilijke vragen om te beantwoorden en de juiste antwoorden, dat wil zeggen de antwoorden die tot de maximale hoeveelheid geluk leiden, zullen van allerlei omstandigheden afhangen. De optimale antwoorden zullen mogelijk nooit worden gevonden, maar benadering ervan lijkt niet principieel onmogelijk. Aangezien het bij geluk om een gevoel gaat, zou de vraag wat leidt tot maximaal geluk in beginsel te beantwoorden moeten zijn op basis van empirisch onderzoek. Dergelijk onderzoek vindt momenteel al plaats, ${ }^{11}$ maar het zou systematischer en op grotere schaal gedaan moeten worden.

Maar naast deze praktische kwesties is er ook een principieel probleem. Om vast te stellen wat de totale hoeveelheid geluk zal maximaliseren, lijkt het nodig te zijn om de toekomst te voorspellen. Dat is nog moeilijker dan het uitzoeken waar mensen gelukkig van worden. Dit is inderdaad een serieus probleem en ik zal er kort drie dingen over zeggen. Ten eerste geldt dat de moeilijkheid om de toekomst te voorspellen groter wordt naarmate het om een verder verwijderde toekomst gaat. Dat zou reden kunnen zijn om aan de te verwachten gevolgen van regelgeving minder belang te hechten naarmate die gevolgen verder in de toekomst liggen. Gevolgen die ver genoeg weg liggen zouden daardoor genegeerd kunnen worden. Ten tweede pleit de onzekerheid van de toekomst voor wat Popper 'piecemeal engineering' noemde; ${ }^{12}$ het op kleine schaal aanbrengen van veranderingen in de samenleving zodat bijsturen als het fout dreigt te lopen zonder al te veel moeite kan.

11 Zie www.pursuit-of-happiness.org/science-of-happiness/measuring-happiness/ (voor het laatst bezocht op 9 december 2014) en de World Happiness Reports (worldhappiness.report/; voor het laatst bezocht op 10 september 2015) en Layard 2011. 
De derde tegenwerping tegen het voorspelbaarheidsbezwaar is wellicht het meest principiële. Als de toekomst moeilijk te voorspellen is - en dat is zij - is dat geen bezwaar tegen een theorie over welke regels het best gemaakt kunnen worden, maar hooguit een probleem bij het handelen overeenkomstig die theorie. De moeilijkheid om te bepalen wat zal leiden tot de maximale hoeveelheid geluk kan geen reden zijn om het utilisme te verwerpen.

Wellicht kan een voorbeeld dit duidelijker maken. Als men zijn autosleutels is verloren, moet men die zoeken op de plaats waar ze werden verloren. Het heeft geen zin om ze te zoeken onder de lantaarnpaal omdat het daar licht is. De sleutels moeten worden gezocht op de plaats waar ze waarschijnlijk liggen, ook al is het daar donker.

Net zo geldt dat als die wet moet worden gemaakt die tot het meeste geluk leidt, het weinig zin heeft om een wet te kiezen op grond van een ander criterium. Dat geldt ook als het veel eenvoudiger is om na te gaan of aan dat andere criterium is voldaan. Zo is het voor een wetgever gemakkelijker om af te gaan op de voorkeuren van de bevolking dan om te bepalen wat de bevolking het meest gelukkig maakt. Maar het geluk is bepalend voor wat de beste wetgeving is, niet de voorkeuren. Wellicht zou de wetgever kunnen afgaan op voorkeuren als de best haalbare benadering van wat mensen gelukkig maakt, maar niet als alternatief voor het gelukscriterium.

\subsection{Democratie}

Een tweede belangrijk argument tegen het utilisme als richtlijn voor de wetgever is dat de inhoud van regelgeving bepaald dient te worden door een democratische procedure en niet door inhoudelijke maatstaven. Er zijn twee soorten redenen te bedenken waarom de wetgever zich niet moet laten leiden door inhoudelijke argumenten die aan geluk zijn ontleend, maar door de wil van de (parlementaire) meerderheid. De ene reden is dat democratie leidt tot een gelukkiger samenleving; de andere reden is dat een volk soeverein is en dat daarom de wil van het volk moet worden gerespecteerd, zelfs al zou dat leiden tot minder geluk.

Het is niet uitgesloten dat wetgeving waarvan de inhoud door democratische procedures wordt bepaald leidt tot het meeste geluk. Mensen hechten aan autonomie en een inbreuk op die autonomie door een paternalistische wetgever zal leiden tot een vermindering van geluk. Verder is er het risico dat het afschaffen van democratie leidt tot een dictatuur die er niet eens naar streeft de totale hoeveelheid geluk te maximaliseren. Hier staat tegenover dat het verlies aan autonomie van het volk en het daarmee gepaard gaande verlies aan geluk worden gecompenseerd door inhoudelijk betere wetgeving en daarmee gepaard gaande winst aan geluk. Het is een empirische kwestie wat het meeste geluk oplevert. En dat geldt ook voor het inschatten van de mogelijk verkeerde gevolgen als de wetgever niet meer inhoudelijk wordt aangestuurd en gecontroleerd door het volk. Het is hierbij niet uitgesloten dat een bepaalde vorm van democratie leidt tot de grootste hoeveelheid geluk die haalbaar is, maar zeker is het niet. Daarom zou het de moeite waard zijn om te proberen uit te vinden of, en zo ja welke vorm van, democratie leidt tot 
maximaal geluk. Dit alles past binnen een utilistische benadering en democratie is dan geen argument tegen utilisme, maar een invulling van utilisme.

Men kan ook op principiële gronden voor democratie zijn, ook als dat niet leidt tot een groter geluk. Dat is bijvoorbeeld het geval als men vindt dat de autonomie van mensen een uitgangspunt is waarop geen inbreuk mag worden gemaakt ten behoeve van het grotere geluk van allen. Dit is een principieel bezwaar, dat het utilisme als geheel verwerpt, zonder in te gaan op de vraag wat het utilisme zou impliceren voor democratie, en op de vraag of democratie leidt tot meer of minder geluk. Deze principiële verwerping van het utilisme komt aan de orde in paragraaf 3.4, na de bespreking van het verwante bezwaar dat het utilisme toelaat dat de rechten van mensen worden geschonden.

\subsection{De opoffering van belangen}

Het utilisme gaat ervan uit dat de hoeveelheid geluk moet worden gemaximaliseerd en dat daarbij een verlies aan geluk bij sommigen kan worden gecompenseerd door meer geluk bij anderen. Velen vinden die gedachte verkeerd, misschien zelfs wel weerzinwekkend. Sandel komt bij de bespreking van dit bezwaar met voorbeelden van christenen die voor de leeuwen worden gegooid omwille van de pret van de toeschouwers (ik schrijf opzettelijk niet 'geluk') en - gebaseerd op een verhaal van Ursula LeGuin - van een zielig kind dat onder erbarmelijke omstandigheden opgesloten zit in een kelder om het alom tegenwoordige geluk van de overige inwoners van haar stad te waarborgen. ${ }^{13}$ Zowel het oordeel dat de christenen voor de leeuwen kunnen worden gegooid omwille van het genoegen van de toeschouwers, als het oordeel dat het goed is dat het kind opgesloten blijft omwille van de voorspoed van haar stadgenoten, zijn - zeker op het eerste gezicht - contra-intuïtief. Een morele theorie die dit soort zaken niet principieel afwijst kan niet goed zijn, zo lijkt het. Maar is het echt zo eenvoudig?

Stel u bent de burgemeester van de 'gelukkige stad' waarin niemand lijdt en iedereen gelukkig is, behalve dat ene zielige kind in de kelder. Laten we, om de zaken helder voor ogen te krijgen, aannemen dat die stad Amsterdam is, met zo'n 800.000 inwoners die op één na allen gelukkig zijn. Als burgemeester bent $\mathrm{u}$ in de positie om het zielige kind vrij te laten, waarna ze een 'gewoon' mens wordt. De overige mensen in de stad zullen ook 'gewoon' worden, en moeten leven met regelmatig voorkomende ziekten, armoede, pesterijen, voortijdige sterfgevallen, verkrachtingen, seksueel misbruik van kinderen, enzovoort. Zou het goed zijn als $\mathrm{u}$ dat kind vrij zou laten? En als u dat om principiële redenen zou hebben gedaan - het is immers moreel fout om mensen op te offeren aan andere mensen - hoe gaat $\mathrm{u}$ dan om met de slachtoffers van uw besluit? Wat zou u vertellen aan de ouders die hun kind verliezen ten gevolge van een dronken automobilist, aan de vrouw die op haar 30ste ongeneeslijke borstkanker krijgt, aan de hooggeschoolde Marokkaan die geen slechte baan krijgt omdat hij te hoog geschoold is en geen goed gekwalificeerde baan omdat hij een Marokkaan is? Zou u vertellen dat het 
zielige kind niet aan hen allen mocht worden opgeofferd? Zij zouden u ongetwijfeld vragen of zij dan wel aan dat kind mochten worden opgeofferd.

Mijn excuses dat ik even sentimenteel werd; dat krijg je als je een beroep gaat doen op morele intuïties in plaats van argumenten. Het meer principiële punt is dat de kwestie van het opofferen bepaald wordt door de manier waarop het probleem wordt geformuleerd. Richten we onze aandacht enkel op de enkeling of de minderheid die wordt opgeofferd aan de massa of aan de meerderheid, of houden we ook serieus rekening met de belangen van de massa of de meerderheid? Het sterke punt van het utilisme is dat het de laatste benadering kiest; iedereen telt in gelijke mate mee. En dan is het onvermijdelijk dat sommigen minder krijgen (of houden) dan ze zonder utilisme zouden hebben gehad. ${ }^{14}$

Deze tegenwerping tegen het bezwaar wint nog aan kracht als we ons richten op de taak van de wetgever. Een wetgever moet algemene regels maken en daarbij moet rekening worden gehouden met ieders belangen. Het is onvermijdelijk dat niet steeds de belangen van iedereen optimaal kunnen worden behartigd. Eén manier om dit te omschrijven is te zeggen dat de belangen van sommigen aan de belangen van anderen worden 'opgeofferd'. Ja, in zekere zin is dat zo, en in de echte wereld is dat onvermijdelijk.

Dat het utilisme toelaat om de belangen van sommigen op te offeren aan de belangen van anderen is daarom geen bezwaar tegen het utilisme. Sterker nog, gegeven de onvermijdelijkheid van de opoffering van belangen doet het utilisme het eigenlijk nog heel goed. Het is onpartijdig, het kiest voor de juiste belangen (enkel echte belangen, die werkelijk leiden tot meer geluk; geen ondoordachte voorkeuren, of domme geldzucht) en het past de meest objectieve test toe die denkbaar is, namelijk het maximaliseren van het geluk.

Daar komt nog bij dat het hier verdedigde utilisme niet van individuele mensen verlangt dat ze hun eigen belangen opofferen ten behoeve van het collectief. Wat $\mathrm{ik}$ hier verdedig is een theorie over wat een wetgever zou moeten doen. Die wetgever heeft tot taak het algemeen belang te dienen. ${ }^{15}$ Individuele personen hoeven dat niet per se te doen, althans die mogelijkheid wil ik hier open laten. Het kan dan voor individuele personen verstandiger zijn om de eigen belangen te behartigen. Zo zou het voor het zielige kind in de gelukkige stad verstandig kunnen zijn om te proberen uit de kelder te ontsnappen.

\subsection{De opoffering van rechten}

Maar wellicht is de kwestie een andere. Wellicht gaat het helemaal niet om het afwegen van belangen, maar is het zo dat individuen rechten hebben die hen niet

Men zou bij dit voorbeeld kunnen tegenwerpen dat de burgemeester van Amsterdam wel verantwoordelijk is voor het opsluiten van het kind, maar niet alles wat de burgers 'gewoon' overkomt. Het is goed mogelijk dat 'men' dat zo vindt, maar een keuze voor utilisme impliceert mogelijk ook een keuze voor anders nadenken over verantwoordelijkheid.

15 Dat de wetgever die taak heeft is een vooronderstelling van mijn betoog. Zelf zie ik die taak als behorend bij de rol van wetgever. 
zomaar mogen worden afgepakt. Mensen hebben rechten en rechten verschillen van belangen in het feit dat ze niet enkel meespelen in een belangenafweging, maar dat ze - in de door Dworkin populair geworden terminologie - een soort 'troefkaarten' zijn die het winnen van gewone redenen. ${ }^{16}$ Als iemand een recht heeft, is dat een reden om dat recht te honoreren en tevens een reden om (een aantal van de) daarmee conflicterende belangen niet mee te tellen.

Laat dit zo zijn, maar dat zegt nog niets over welke rechten mensen hebben. Hebben mensen rechten net zoals ze armen en benen hebben, kant en klaar in de 'natuur' en wachtend op ontdekking? Dat is niet zo aannemelijk. Hebben mensen dan enkel die rechten die hun door een stelsel van rechtsregels expliciet worden toegekend? Zo ja, dan is dat voor de huidige discussie minder relevant, want de kwestie is juist welk positief recht de wetgever moet maken.

Maar er is nog een tussenweg: wellicht hebben mensen morele rechten, die niet kant en klaar in de natuur te vinden zijn, maar die ook niet afhankelijk zijn van het positieve recht. Mensen zouden die rechten hebben als dat past in de juiste morele theorie. ${ }^{17}$ Stel dat dit zo zou zijn, dan is het nog niet vanzelfsprekend dat de wetgever deze rechten zou moeten respecteren. Dat hangt er namelijk van af of de veronderstelde morele rechten het troefkaartkarakter hebben dat Dworkin aan rechten toeschrijft. Ik wil deze kwestie hier enkel aanroeren, maar niet verder bespreken. Maar ik zal wel nader ingaan op de vraag of mensen morele rechten hebben waarop moreel bezien geen inbreuk mag worden gemaakt, ook al zou dat leiden tot meer geluk. De meest prominente moderne vertegenwoordiger van deze opvatting was John Rawls.

Zoals bekend verdedigde Rawls de 'prioriteit van het juiste boven het goede'. ${ }^{18}$ Daarmee bedoelde hij dat er basisregels voor een samenleving zouden moeten zijn die worden gedefinieerd onafhankelijk van de opvattingen die mensen hebben over hoe een ideale samenleving eruitziet. Deze basisregels, die bij Rawls de vorm kregen van twee rechtvaardigheidsbeginselen en twee voorrangsregels, zouden een neutraal kader moeten zijn waarbinnen mensen hun eigen idealen kunnen nastreven. Volgens Rawls zou dit neutrale kader onder meer maximale vrijheden moeten omvatten. Deze vrijheden vormen als het ware een 'no-goarea' waar de overheid niet binnen mag komen, ook niet om het algemeen belang te behartigen of om de totale hoeveelheid geluk te maximaliseren. Binnen dit als het ware vooraf gedefinieerde kader zouden mensen invulling mogen geven aan hun eigen idealen.

Rawls claimde dat zijn rechtvaardigheidsbeginselen zouden worden gekozen door mensen als zij hun keuze onder eerlijke omstandigheden zouden moeten maken, ${ }^{19}$ of als zij rekening zouden houden met de politieke realiteit dat ze moeten samen-

17 Zo was John Stuart Mill van opvatting dat mensen rechten moesten hebben als en voor zover dat voortvloeide uit de maximalisering van geluk. Zie Mill 1863, hoofdstuk V.

18 Rawls 1999.

19 Rawls 1972. 
leven met andere mensen die er andere ideeën over de ideale samenleving op na houden dan zij zelf. ${ }^{20}$ Maar het is voor discussie vatbaar of Rawls' eerlijke omstandigheden een goede indicator opleveren voor hoe een wetgever zou moeten handelen. Rawls was namelijk de opvatting toegedaan dat de eerlijke omstandigheden er onder meer uit zouden bestaan dat mensen niet zouden weten wat hun visie op de ideale samenleving is. Door deze aanname te maken neemt Rawls al een flink voorschot op de conclusie die hij zal trekken, te weten dat er rechten moeten zijn die voorafgaan aan pogingen om een ideale samenleving te realiseren. Nagel stelde dan ook terecht dat Rawls' afleiding van zijn rechtvaardigheidsbeginselen uit de omschrijving van de beginpositie eerder een wijze van uiteenzetten is van zijn morele opvattingen dan een rechtvaardiging ervan. ${ }^{21}$

Principiëler dan de kritiek dat Rawls' claim over de prioriteit van rechten voor betwisting vatbaar is, is de constatering dat het bestaan van onaantastbare rechten de uitkomst is van een morele theorie. ${ }^{22}$ De claim dat dergelijke rechten bestaan is niet sterker dan de theorie waaruit deze claim voortvloeit. De directe implicatie hiervan is dat het bestaan van rechten niet kan worden gebruikt om een morele theorie te verwerpen. Het is goed mogelijk om, zoals Rawls wilde, ${ }^{23}$ prioriteit toe te kennen aan rechten boven opvattingen over wat het goede leven inhoudt. Maar het is evenzeer mogelijk om met John Stuart Mill te betogen dat het gelukscriterium bepalend moet zijn voor welke rechten mensen moeten hebben. Kortom, rechten zijn een uitvloeisel van theorievorming en kunnen daarom niet worden aangehaald om een bepaalde theorie (het utilisme) bij voorbaat te verwerpen. Als men het utilisme wil bekritiseren omdat het inbreuk maakt op rechten van individuen komt die kritiek er uiteindelijk op neer dat het utilisme in strijd is met een andere morele theorie, namelijk de theorie waarop de morele rechten zijn gebaseerd. De discussie moet dan gaan over de vraag welke van beide morele theorieën de betere is. Ik zal hieronder betogen dat het antwoord op deze vraag gezocht moet worden in een coherente theorie van 'alles'.

\subsection{Autonomie}

In paragraaf $3.2 \mathrm{kwam}$ de kwestie aan de orde of de wetgever niet enkel procedureel gelegitimeerd zou moeten worden, in plaats van inhoudelijk gebonden te zijn. Dat zou dan te maken hebben met de autonomie (soevereiniteit) van het volk dat door de wetgever vertegenwoordigd wordt.

Maar is het wel zo dat het volk autonoom is? Ik heb het nu dus niet over de vraag of een volk met zelfbeschikkingsrecht gelukkiger is. Er valt veel voor te zeggen dat dit zo zou zijn, maar dan zitten we al in het utilistische discours. De principiële kwestie waar we het nu over moeten hebben is of geluk überhaupt relevant is als een volk, vertegenwoordigd door zijn wetgever, mag doen wat het wil, hoe ongelukkig het daar ook door wordt. 
Als we de kwestie op deze laatste manier formuleren wordt de parallel duidelijk met de kwestie of mensen morele rechten hebben waarop geen inbreuk mag worden gemaakt om welke reden dan ook en dus ook niet omwille van het grotere geluk. De conclusie is dan ook dezelfde als de conclusie met betrekking tot de natuurlijke rechten. Het is denkbaar dat er een morele theorie is die mensen of een volk autonomie toekent en die beter is dan het utilisme. Of dat zo is moet blijken uit morele argumentatie en daarbij dient, zo zal ik betogen, coherentie een belangrijke rol te spelen. Maar wat niet kan is om autonomie aan te nemen als onbeargumenteerd uitgangspunt en het utilisme te verwerpen omdat het inbreuk zou maken op die autonomie.

\section{Morele intuïties en normatieve methode}

Een gangbaar punt van kritiek tegen het utilisme is dat deze theorie kan leiden tot waardeoordelen die sterk tegen onze intuïties ingaan over wat goed of fout is in een concreet geval. Ik schrijf 'kan', want vaak komt de kritiek er niet zozeer op neer dat het utilisme echt leidt tot contra-intuïtieve waardeoordelen, maar dat het niet bij voorbaat uitsluit dat dergelijke waardeoordelen gerechtvaardigd zouden zijn. Zo sluit het utilisme niet bij voorbaat uit dat het goed kan zijn om mensen aan wilde dieren te voederen omwille van het vermaak van omstanders, of dat het goed kan zijn om onschuldige mensen te 'straffen' omwille van de sociale vrede. Of het utilisme echt tot dergelijke waardeoordelen leidt valt nog te bezien, maar voor velen is de enkele mogelijkheid dat het ertoe zou leiden al voldoende reden om het utilisme te verwerpen.

Hoe serieus moeten we dergelijke kritiek nemen? Hoe 'erg' is het als een morele theorie ingaat tegen waardeoordelen die we intuïtief vellen in concrete gevallen? Het is de moeite waard om ter beantwoording van deze vraag dieper in te gaan op de methode waarmee we waardeoordelen, en met name de daaraan ten grondslag liggende evaluatieve beginselen, rechtvaardigen.

\subsection{Inductie}

Een relatief eenvoudige visie op de rol van morele intuities is dat deze te vergelijken is met de rol van zintuiglijke waarnemingen in de empirische wetenschappen. Die rol is niet onomstreden, maar een eenvoudige visie daarop komt op het volgende neer. De natuur gehoorzaamt aan bepaalde (natuur)wetten. Deze wetten zelf kunnen we niet waarnemen, maar wat we wel kunnen waarnemen is de impact van de natuurwetten op de gebeurtenissen om ons heen. Deze gebeurtenissen nemen we met onze zintuigen waar en we kunnen de natuurwetten inductief afleiden uit onze waarnemingsgegevens. Soms zal een waarneming niet correct zijn en daar moeten we bij de inductie rekening mee houden door af en toe een waarneming buiten beschouwing te laten die niet in de theorie past. Maar het primaat ligt bij de waarnemingen en de theorie over de natuurwetten is gebaseerd op en afhankelijk van de waarnemingsgegevens en niet andersom. 
Analoog kunnen we morele intuïties over concrete situaties beschouwen als een soort waarnemingen van de morele werkelijkheid, een werkelijkheid die gehoorzaamt aan morele wetten, alweer analoog aan de wijze waarop de natuur zou gehoorzamen aan natuurwetten. En net zoals we waarnemingsgegevens kunnen gebruiken om via inductie de natuurwetten te ontdekken, kunnen we morele intuïties gebruiken om via inductie de morele wetten te ontdekken.

Als deze inductieve methode voor de ethiek correct zou zijn, dan spelen morele intuities een cruciale rol bij het formuleren van morele normen en maatstaven. Weliswaar is het mogelijk dat een enkele intuitie verkeerd is en terzijde moet worden gelegd bij de formulering van de wetten en maatstaven, maar als er een structurele discrepantie bestaat tussen onze intuïtieve waardeoordelen en een morele theorie, dan moeten we de theorie opgeven.

Nog afgezien van de vraag of de inductivistische visie op het verwerven van natuurwetenschappelijke kennis correct is, is het dubieus of die visie getransplanteerd kan worden naar het domein van de ethiek. Het is namelijk een vooronderstelling van het hierboven beschreven inductivisme in de natuurwetenschappen dat de natuur gehoorzaamt aan wetten die bestaan onafhankelijk van onze kennis en zeker ook onafhankelijk van de vraag of we die wetten aanvaarden. De natuurwetenschap beoogt enkel de reeds bestaande wetten te beschrijven. Niet velen zullen geneigd zijn om analoog hieraan aan te nemen dat er morele wetten zijn, die bestaan onafhankelijk van onze kennis of aanvaarding daarvan en die we in de ethiek proberen te beschrijven op basis van onze intuïtieve waarnemingen van hun gevolgen. Het is veeleer andersom: de morele wetten en maatstaven zijn er eerst, omdat we die feitelijk aanvaarden (positieve moraal) of omdat we die zouden moeten aanvaarden als we rationeel zouden zijn (kritische moraal) en onze intuïtieve waardeoordelen zijn het resultaat van die wetten en maatstaven. Als onze intuïties niet in overeenstemming zijn met de morele wetten en maatstaven die we feitelijk (of rationeel zouden moeten) aanvaarden, dan zijn de intuïties fout en moeten we ze als onjuist terzijde leggen. De parallel tussen inductieve theorievorming in de natuurwetenschappen en ethiek gaat niet op en daarom kan deze parallel geen rechtvaardiging vormen voor een belangrijke rol van morele intuïties in de morele theorievorming.

\subsection{Reflectief evenwicht (de primitieve versie)}

Een verbetering ten opzichte van de inductivistische benadering in de ethiek is de door Rawls gepopulariseerde methode van het reflectief evenwicht. Van die methode kunnen een primitieve en een verfijnde variant worden onderscheiden. ${ }^{24}$ De verfijnde variant is sterk verwant aan het coherentisme dat ik hieronder zal bespreken. De primitieve variant lijdt in beginsel aan dezelfde problemen als het inductivisme.

Deze primitieve variant houdt in dat de toetsing van morele beginselen en morele intuïties tweerichtingsverkeer is. Het is niet zo dat de intuïties worden verabso-

24 Het is voor mijn betoog niet van belang of een van deze beide varianten door Rawls zelf werd aangehangen en zo ja, welke variant dat zou zijn, en ik zal die kwestie dan ook laten rusten. 
luteerd en dat bij een conflict tussen een potentieel beginsel zoals het beginsel van geluksmaximalisering en een intuïtief waardeoordeel het beginsel het steeds dient te verliezen. Er moet goed worden nagedacht (het reflectieve aspect van het reflectief evenwicht) over wat bij een dreigend conflict gehandhaafd moet worden, het beoogde morele beginsel of het intuïtieve waardeoordeel.

Verder is het niet per se het geval dat morele beginselen enkel uit de concrete waardeoordelen worden geïnduceerd; het is ook mogelijk dat een bepaald moreel beginsel op zuiver theoretische gronden wordt overwogen. Maar uiteindelijk moet het zo zijn dat de concrete waardeoordelen die uit hypothetisch aanvaarde beginselen voortvloeien intuïtief aanvaardbaar zijn, terwijl de uiteindelijk intuitief aanvaarde concrete waardeoordelen hun rechtvaardiging moeten vinden in de aanvaarde morele beginselen.

Deze primitieve versie van de theorie van het reflectief evenwicht is een verbetering ten opzichte van het hierboven omschreven inductivisme om ten minste twee redenen. Ten eerste laat dit reflectief evenwicht toe dat morele beginselen bij wijze van hypothese worden aanvaard op zuiver theoretische gronden. En ten tweede doet het meer recht aan het inzicht dat morele intuities fout kunnen zijn en dat ze fout kunnen zijn, niet omdat het een soort foutieve 'waarnemingen' zouden zijn, maar omdat ze geen steun vinden in de aanvaarde morele beginselen. Toch blijft het probleem dat het inductivisme plaagt ook bestaan bij deze primitieve versie van het reflectief evenwicht. Dat probleem is dat er zelfstandige waarde wordt gehecht aan intuïtieve waardeoordelen, terwijl daarvoor geen grond bestaat in een objectieve morele werkelijkheid die gekend wordt via onze intuïties. Wil dit dan zeggen dat er in ethische theorievorming helemaal geen plaats is voor intuitieve waardeoordelen? Niet per se, maar die plaats is bescheiden en er is een ingewikkelder methode voor nodig om die bescheiden plaats aan te wijzen. Dat is de methode van het coherentisme.

\subsection{Rechtvaardiging door coherentie}

Coherentisme is een methode in de kennisleer die het belangrijkste alternatief is voor het funderingsdenken. Het funderingsdenken gaat ervan uit dat onze kennis uiteindelijk is gebaseerd op een fundament dat geen verdere rechtvaardiging behoeft. Een populaire kandidaat voor zo'n fundament is de zintuiglijke waarneming, maar in het hierboven beschreven morele inductivisme spelen intuïties een vergelijkbare rol. Problematisch in het funderingsdenken is dat het beoogde fundament nogal willekeurig lijkt te zijn. Waarom zouden zintuiglijke waarnemingen zo'n fundamentele rol moeten spelen? Het is verleidelijk om die vraag te beantwoorden, maar zodra men dat doet heeft men de zintuiglijke waarneming als fundament opgegeven: de redenen waarom we een fundamentele rol aan zintuiglijke waarneming zouden moeten toekennen hebben de plaats van de waarneming als fundament overgenomen. Uiteindelijk is dit bezwaar beslissend en het funderingsdenken moet worden verworpen ten gunste van een coherentiebenadering. Het aantrekkelijke van een coherentiebenadering is dat de zoektocht naar een fundament voor de kennis wordt opgegeven. Een bepaald stukje kennis ontleent zijn rechtvaardiging aan het feit dat het deel uitmaakt van een groter geheel aan 
kennis dat samenhangend (coherent) is. Alle onderdelen van dit grotere geheel ontlenen hun rechtvaardiging aan hun lidmaatschap van dit grotere geheel en de verschillende onderdelen houden elkaar als het ware overeind, zoals de stokken in een bundel rechtop staande stokken die tegen elkaar leunend elkaar overeind houden. De metafoor van de bundel stokken geeft mooi aan waar het bij coherentie om draait, maar een coherentietheorie van gerechtvaardigde kennis moet aanmerkelijk preciezer zijn dan wat de metafoor kan bieden. Ik zal een poging doen om de coherentietheorie voldoende uit te leggen om duidelijk te maken wat de beperkte rol van intuïtieve waardeoordelen is in morele theorievorming. ${ }^{25}$

Kennis wordt vaak omschreven als ware en gerechtvaardigde mening. Coherentietheorieën over kennis hebben met name betrekking op de vraag wanneer meningen gerechtvaardigd zijn. In dit verband is het woord 'mening' overigens minder gelukkig, want het suggereert dat coherentie slechts betrekking kan hebben op opvattingen over hoe de werkelijkheid in elkaar zit, over de feiten. Het is handiger om ook regels en beginselen, waarden, handelingen en waardeoordelen onder coherentie te vatten. Het woord 'meningen' wordt hieronder dan ook gebruikt om al deze categorieën te omvatten. De mening over een handeling is dan bijvoorbeeld de mening dat een handeling juist is. Aldus opgevat is coherentisme dus ook een theorie over de methode voor normatief redeneren.

De centrale gedachte achter coherentietheorieën is dat de onderdelen van een verzameling meningen, individuele meningen dus, gerechtvaardigd zijn als ze deel uitmaken van een coherente verzameling meningen. Daarbij wordt coherentie opgevat als wederzijdse steun. Het is niet eenvoudig om aan te geven wat in dit verband onder wederzijdse moeten worden verstaan. ${ }^{26}$ Daarom geef ik er de voorkeur aan coherentie te definiëren in termen van volledigheid en consistentie. Het volgende is een eerste benadering:

Een verzameling meningen is coherent als deze verzameling consistent ${ }^{27}$ is en voor elke propositie aangeeft of deze waar of onwaar is.

Het nadeel van deze definitie is dat een verzameling coherent kan zijn die evidente onwaarheden bevat. Op zich is een onwaarheid niet dodelijk voor coherentie, want het is mogelijk dat een mening gerechtvaardigd is, ook al blijkt die uiteindelijk onwaar te zijn. Maar het gaat ook wat ver om elke volledige en consi-

Uitvoeriger beschrijvingen van de coherentietheorie in kennisleer, ethiek en rechtsfilosofie zijn onder meer te vinden in Bonjour 1985, Lehrer 1992, Thagard 2000, Daniels 2011, Hage 2005, Peczenik 2008, Amaya 2015 en Araszkiewicz \& Šavelka 2013. Overigens wijkt de versie van coherentie die ik hier beschrijf af van de versie die ik heb beschreven in Hage 2013. Dat heeft te maken met de strekking van mijn betoog, dat hier in de eerste plaats over recht en ethiek gaat en niet over kennisleer. De hier beschreven versie is vereenvoudigd en lijdt aan een aantal gebreken waar ik hier niet verder op zal ingaan.

26 Peczenik 2008, p. 132-140 biedt een illustratie van de complicaties waartoe het streven om wederzijdse steun te definiëren kan leiden.

27 De notie van 'consistentie' moet in dit verband ruim worden opgevat, zodat ook regels en waarden betrokken kunnen zijn in een consistentierelatie. 
stente verzameling van meningen de meningen in die verzameling te laten rechtvaardigen. Een middel om dit probleem te verhelpen is om de aanvullende eis te stellen dat de verzameling geen evidente onwaarheden mag bevatten. ${ }^{28}$

Een coherente verzameling meningen is een mooi ideaal, maar in werkelijkheid niet te realiseren, al was het maar omdat de verzameling oneindig groot zou zijn. De rol van deze theoretische constructie is om te fungeren als een test voor de meningen die er werkelijk op na worden gehouden.

Stel dat iemand, laten we haar Jannie noemen, van mening is dat zij de bedelaar die zij nu tegenkomt geen geld moet geven. Zij denkt dat deze mening gerechtvaardigd is, want zij is van mening dat het geven van geld aan bedelaars averechts werkt omdat het de overheid het gevoel geeft dat de bestrijding van armoede niet zo'n erg hoge prioriteit hoeft te hebben. Jannie realiseert zich dat haar intuitieve morele oordeel mede het gevolg is van een inschatting van de gevolgen van haar gedrag en dat die inschatting foutief zou kunnen zijn. De vraag is nu of zij voldoende reden heeft om te denken dat die inschatting juist zal zijn. Zo ja, dan is haar mening over de concrete situatie gerechtvaardigd.

In termen van coherentie beschreven is in dit voorbeeld het volgende het geval. Jannie aanvaardt een concreet moreel oordeel ('Geen geld geven aan de bedelaar'). Dat oordeel maakt deel uit van de verzameling van al haar meningen. Die verzameling is niet coherent, maar wat Jannie nu moet doen is een inschatting maken of haar waardeoordeel nog steeds in haar verzameling van meningen zou zitten in het hypothetische geval dat zij die verzameling zou hebben verbeterd tot een verzameling die wel coherent is. Die inschatting maakt zelf deel uit van haar huidige verzameling van meningen. Als die inschatting positief uitvalt - Jannie denkt nu oprecht dat ook als zij volledig rationeel zou zijn en dat als zij al haar onware meningen heeft vervangen door ware meningen, zij nog steeds van oordeel zou zijn dat zij geen geld aan de bedelaar zou moeten geven - dan is het waardeoordeel gerechtvaardigd.

Het is duidelijk dat deze rechtvaardiging nogal zwak is. Er is geen enkele garantie dat Jannie geen foute inschatting maakt van wat haar oordeel zou zijn als zij volslagen rationeel zou zijn en volmaakte informatie zou hebben. Maar wat kunnen we meer van haar verwachten dan dat zij eerlijk gebruik maakt van de informatie die zij momenteel denkt te hebben, van alle algemeen aanvaarde kennis en van haar onvolmaakte redeneervermogens? Rechtvaardiging houdt in dat iemand voldoet aan de eisen die redelijkerwijs aan haar gesteld kunnen worden. Het is geen hard bewijs dat het gerechtvaardigde waar is.

28 Dit is een lapmiddel omdat het de notie van waarheid introduceert in een definitie van wat gerechtvaardigd is. Bovendien is de notie van een 'evidente' onwaarheid nogal subjectief. Het oplossen van dit probleem - en ik denk dat het opgelost kan worden - zou ons echter te ver op het gebied van de kennisleer voeren. Zie Hage 2013 voor mijn poging om aan deze complicaties het hoofd te bieden. 


\subsection{De rol van morele intü̈ties}

Morele intuïties in concrete situaties zijn morele waardeoordelen die we intuïtief, dat wil zeggen niet als resultaat van reflectie, geven. Ze maken deel uit van de verzameling meningen van de persoon die deze oordelen geeft, maar deze verzameling is niet coherent. Wil het intuïtieve oordeel gerechtvaardigd zijn, dan moet het tevens deel uitmaken van de hypothetische coherente verzameling die het resultaat zou zijn van het rationaliseren van de aanvankelijke meningen tot een verzameling die wel coherent is. De rechtvaardiging van het intuïtieve waardeoordeel is dan gebaseerd op het lidmaatschap van deze hypothetische coherente verzameling.

De hypothetische coherente verzameling zal naar alle waarschijnlijkheid ook een morele theorie bevatten die aangeeft welke concrete oordelen juist zijn. Zij zou bijvoorbeeld de rechtvaardigheidstheorie van Rawls kunnen omvatten, maar zij zou ook een versie van het utilisme kunnen omvatten. In het eerste geval zou Rawls' theorie gerechtvaardigd zijn; in het laatste geval zou het utilisme gerechtvaardigd zijn.

De kwestie waar het ons hier om te doen is, is de rol van de intuïtieve waardeoordelen bij het bepalen van wat de betere morele theorie is. Welnu, die rol is beperkt, want het gaat bij de rechtvaardiging van morele theorieën zoals het utilisme niet om de intuïtieve waardeoordelen die iemand erop na houdt, maar om de concrete waardeoordelen die deel uitmaken van een - toegegeven hypothetische - coherente theorie van alles. De oorspronkelijke intuïtieve waardeoordelen kunnen in theorie deel uitmaken van die coherente verzameling, maar er is geen enkele garantie dat dit het geval zal zijn. Voor de uiteindelijke rechtvaardiging van het utilisme zijn enkel die uiteindelijke concrete waardeoordelen van belang; die moeten met het utilisme te verenigen zijn.

Met deze laatste conclusie hebben we ons antwoord op de kritiek dat het utilisme kan leiden tot waardeoordelen die sterk contra-intuïtief zijn. Op zich is dat geen deugdelijke kritiek op het utilisme. Wat nodig is, is een coherente theorie die zowel maatstaven biedt voor de rechtvaardiging van morele oordelen als waardeoordelen over concrete situaties. Intuïtieve waardeoordelen spelen een historische rol bij het construeren van zo een coherente theorie, maar er is geen enkele garantie dat ze nog deel uitmaken van het uiteindelijke resultaat.

\subsection{De waarde van geluk}

In paragraaf 2.2 kwam kort de vraag aan de orde of we uit het gegeven dat mensen van nature geluk nastreven mogen afleiden dat geluk nastrevenswaardig is. Op basis van de hierboven geschetste coherentietheorie kunnen we nu zien dat deze redeneerstap niet per se verkeerd zou zijn, omdat hij een naturalistische drogreden zou behelzen. Als mensen van nature geluk nastreven vinden ze, impliciet, geluk intuïtief nastrevenswaardig. Die aanvankelijke mening is slechts gerechtvaardigd als hij nog steeds deel zou uitmaken van de verzameling meningen van mensen als ze die verzameling zouden hebben gerationaliseerd. Een dergelijk rationaliseringsproces begint niet vanuit het niets, maar bestaat uit correcties 
op de verzameling meningen zoals die op een bepaald moment bestaat. Het is zeker mogelijk dat de mening dat geluk nastrevenswaardig is in de loop van het rationaliseringsproces wordt opgegeven, maar dan moet daar wel een reden voor zijn. Er zit een tendens tot conservatisme in een verzameling meningen. Als zo'n reden niet opduikt tijdens het proces van rationalisering, blijft de mening dat geluk nastrevenswaardig is staan, en als dit gedurende het gehele proces het geval is, dan is uiteindelijk die mening gerechtvaardigd omdat hij deel uitmaakt van een coherente verzameling meningen. ${ }^{29}$

\section{Utilisme vs. Rawls}

We hebben hierboven gezien dat het utilisme een aantrekkelijk uitgangspunt is voor een wetgever, omdat het erin slaagt de irrationaliteit te voorkomen van het onbeargumenteerd bevorderen of verwerpen van bepaalde soorten gedrag en omdat het richtlijnen voor gedrag koppelt aan iets dat inherent waardevol is (geluk).

Toch lijken er serieuze bezwaren aan het utilisme te zijn verbonden. Een daarvan is dat de wetgever procedureel gebonden moet zijn (democratie) en niet inhoudelijk. Een tweede bezwaar is dat het utilisme inbreuk maakt op de morele rechten van mensen. En een derde bezwaar is dat het kan leiden tot waardeoordelen die sterk contra-intuitief zijn. Ik heb beargumenteerd dat de eerste twee bezwaren er uiteindelijk op neerkomen dat er een betere morele theorie is die aan mensen autonomie en rechten toekent. Dat er zo'n betere theorie zou zijn, moet worden aangetoond binnen het kader van een coherente theorie van 'alles'. Het derde bezwaar is niet steekhoudend, tenzij kan worden aangetoond dat de aanvankelijk enkel intuïtieve waardeoordelen gerechtvaardigd zijn, wederom binnen het kader van een coherente theorie van 'alles'.

Al met al komt het erop neer dat de rechtvaardiging van het hanteren van het utilisme als richtlijn voor de wetgever afhangt van de kwestie of het utilisme als beste evaluatieve theorie naar voren zou komen in een coherente theorie van 'alles'. Dat dit inderdaad het geval is, kan enkel worden aangetoond door zo'n coherente theorie te construeren en dat is, zoals we al zagen, weinig realistisch. Het best haalbare alternatief is te laten zien dat het utilisme beter is dan zijn concurrenten indien het wordt geëvalueerd aan de hand van criteria waarvan we, op grond van coherentie, mogen aannemen dat ze zelf gerechtvaardigd zijn. Ik zal proberen dit te laten zien voor de vergelijking tussen het utilisme en de rechtvaardigheidstheorie van Rawls (verder: Rawls).

Om te beginnen is het de vraag of het utilisme en Rawls in praktijk veel van elkaar verschillen. Toegegeven, in theorie zijn de verschillen substantieel, maar in de praktijk zou het goed kunnen zijn dat een samenleving die aan de vereisten van Rawls voldoet leidt tot relatief veel geluk. Net zomin als het goed is het utilisme 
te verwerpen omdat het in theorie tot slechte gevolgen zou kunnen leiden, is het goed om Rawls te verwerpen omdat het tot een suboptimale hoeveelheid geluk zou kunnen leiden. Jammer genoeg ontbreekt, voor zover ik weet, de feitelijke informatie over hoe het de verschillende theorieën vergaat als ze in de praktijk zouden worden toegepast. De conclusie die we daaruit zouden moeten trekken is dat het hoog tijd wordt om dit soort feitelijke informatie te vergaren.

Zonder de relevante feitelijke informatie is de best haalbare strategie de twee theorieën toch maar theoretisch te vergelijken. Dan heeft het utilisme mijns inziens duidelijk de betere kaarten en dat heeft er alles mee te maken dat de waarde van vrijheden (Rawls' eerste beginsel) er toch vooral is in gelegen om mensen gelukkiger te maken door ze van die vrijheden te laten profiteren. Als de vrijheden leiden tot meer geluk, worden die vrijheden niet alleen door Rawls maar ook door het utilisme gepropageerd. De cruciale test bestaat daarom in de situatie waarin het bestaan van de vrijheden die Rawls voorstaat, leidt tot minder geluk. Kan het dan toch zijn dat een samenleving beter af is met vrijheden die mensen ongelukkiger maken? Dit is uiteindelijk de kwestie of vrijheden intrinsieke waarden opleveren naast geluk. Rawls zelf zou waarschijnlijk zeggen van niet, want hij verdedigt vrijheden als primaire goederen, goederen die instrumentele waarde hebben voor elk mogelijk levensplan. ${ }^{30}$

Dan het verschilbeginsel, dat wordt gerealiseerd via Rawls' tweede rechtvaardigheidsbeginsel. Toegepast op geluk leidt het verschilbeginsel tot de vraag wat beter is, een samenleving die maximaal geluk kent, of een samenleving waarin degene die het slechtst af is toch nog zo veel mogelijk geluk kent? Het in paragraaf 3.3 opgevoerde voorbeeld van de gelukkige stad laat mijns inziens, juist doordat het zo extreem is, goed zien waar het om gaat. Moeten alle burgers van de stad worden opgeofferd aan het zielige kind in de kelder, of andersom? Ik zou zeggen andersom, en dat impliceert de verwerping van het verschilbeginsel.

Let wel, ik ontken niet dat het verschilbeginsel waardevol is, maar het is vooral waardevol als het gaat om geld of andere instrumenteel waardevolle dingen. Het wordt anders als het gaat om intrinsieke waarden, zoals geluk. Daarvoor geldt dat ze gemaximaliseerd moeten worden, zonder acht te slaan op de verdeling ervan. Dit verschil tussen instrumentele en intrinsieke waarden heeft voor mijn gevoel - ik geef toe: dat is niet echt een argument - te maken met de wet van het afnemende grensnut, die wel vaak geldt voor instrumentele waarden, maar nooit voor intrinsieke waarden. ${ }^{31}$

Beide rechtvaardigheidsbeginselen van Rawls moeten het afleggen tegen het utilisme. Uitgaande van de simplificerende aanname dat het bij een keuze tussen richtlijnen voor een wetgever zou gaan tussen een rechtengebaseerde opvatting zoals die van Rawls en het utilisme blijkt het utilisme de theorie die het beste te verdedigen valt. Dat is, zolang er geen betere concurrent voor het utilisme op het

30 Rawls 1972, p. 62.

31 Het betoog in deze alinea is wel heel kort door de bocht. De betekenis van het onderscheid tussen instrumentele en intrinsieke waarden voor de vraag wat belangrijker is, kwantiteit of distributie (gelijkheid), verdient een uitvoeriger bespreking. Maar juist omdat het uitvoerig zou moeten zijn, is er hier geen plaats voor. 
toneel is, reden om het utilisme te hanteren als richtlijn voor een wetgever die het zo goed mogelijk voor heeft met de mensen waarvoor hij regels maakt.

\section{Aangehaalde literatuur}

\section{Amaya 2015}

A. Amaya, The Tapestry of Reason, Oxford: Hart 2015.

Araszkiewicz \& Šavelka 2013

M. Araszkiewicz \& J. Šavelka (red.), Coherence: Insights from Philosophy, Jurisprudence and Artificial Intelligence, Dordrecht: Springer 2013.

\section{Bentham 1789}

J. Bentham, An Introduction to the Principles of Morals and Legislation, edited by J.H. Burns \& H.L.A. Hart, Londen: Methuen 1970, 1ste druk 1789.

\section{Bonjour 1985}

L. Bonjour, The Structure of Empirical Knowledge, Cambridge, MA: Harvard University Press 1985.

\section{Daniels 2011}

N. Daniels, 'Reflective Equilibrium', in: E.N. Zalta (red.), The Stanford Encyclopedia of Philosophy (Spring 2011 Edition), <plato.stanford.edu/archives/spr2011/entries/ reflective-equilibrium>.

\section{Dolan \& Peasgood 2008}

P. Dolan \& T. Peasgood, 'Measuring Well-Being for Public Policy: Preferences or Experiences', in: E.E. Posner \& C.R. Sunstein (red.), Law \& Happiness, Chicago: University of Chicago Press 2010, p. 5-31.

\section{Driver 2012}

J. Driver, Consequentialism, Londen: Routledge 2012.

\section{Dworkin 1985}

R. Dworkin, A Matter of Principle, Oxford: Clarendon Press.

\section{Hage 2005}

J. Hage, 'Law and Coherence', in: J. Hage, Studies in Legal Logic, Dordrecht: Springer 2005, p. 33-68.

\section{Hage 2013}

J. Hage, 'Three kinds of coherentism', in: M. Araszkiewicz \& J. Šavelka (red.), Coherence: Insights from Philosophy, Jurisprudence and Artificial Intelligence, Dordrecht: Springer 2013, p. 1-32.

\section{Haybron 2011}

D. Haybron, 'Happiness', in: E.N. Zalta (red.), The Stanford Encyclopedia of Philosophy (Fall 2011 Edition), <plato.stanford.edu/archives/fall2011/entries/happiness/>.

\section{Layard 2011}

R. Layard, Happiness: Lessons from a New Science, 2de druk, Londen: Penguin 2005.

\section{Lehrer 1992}

K. Lehrer, 'Coherentism', in: J. Dancy \& E. Sosa (red.), A Companion to Epistemology, Oxford: Blackwell 1992, p. 67-70.

\section{Mill 1863}

John Stuart Mill, Utilitarianism, meerdere uitgaven, waaronder < www.utilitarianism. $\mathrm{com} / \mathrm{mill1}$.htm $>$.

\section{Murphy \& Nagel 2002}

L. Murphy \& T. Nagel, The Myth of Ownership, Taxes and Justice, Oxford: Oxford University Press 2002. 


\section{Nagel 1973}

T. Nagel, 'Rawls on Justice', in: Philosophical Review LXXXII (1973), p. 220-234.

\section{Parfit 2011}

D. Parfit, On What Matters, Vol. 1, Oxford: Oxford University Press 2011.

\section{Peczenik 2008}

A. Peczenik, On Law and Reason, 2de druk, Dordrecht: Springer 2008.

\section{Pollock \& Cruz 1999}

J.L. Pollock \& J. Cruz, Contemporary Theories of Knowledge, 2de druk, Lanham: Rowman and Littlefield 1999.

\section{Popper 1957}

K.R. Popper, The Povery of Historicism, Londen: Routledge and Kegan Paul 1957.

\section{Rawls 1972}

J. Rawls, A Theory of Justice, Oxford: Oxford University Press 1972.

\section{Rawls 1999}

John Rawls, 'The Priority of Right and Ideas of the Good', in zijn Collected Papers, Cambridge, MA: Harvard University Press 1999, p. 449-472.

\section{Rawls 1993}

J. Rawls, Political Liberalism, New York: Columbia University Press 1993.

\section{Sandel 2011}

M.J. Sandel, Rechtvaardigheid. Wat is de juiste keuze?, Utrecht: Ten Have 2011.

\section{Sayre-McCord 2007}

G. Sayre-McCord, 'Coherentism and the Justification of Moral Beliefs', in: R. ShaferLandau (red.), Ethical Theory: An Anthology, Oxford: Blackwell 2007, p. 123-140.

\section{Sinnott-Armstrong 2014}

W. Sinnott-Armstrong, 'Consequentialism', in: E.N. Zalta (red.), The Stanford Encyclopedia of Philosophy (Spring 2014 Edition), <plato.stanford.edu/archives/spr2014/ entries/consequentialism/>.

\section{Thagard 2000}

P. Thagard, Coherence in Thought and Action, Cambridge, MA: MIT Press 2000. 